\title{
Evaluation of Blended Cooking Banana (Musa spp) and Soybean (Glycinemax (L.) Merrill) as Food Complement for Infants
}

\author{
Agomoh-Adeoye Q. C. ${ }^{1}$, Ezenwa H. C. ${ }^{2}$ \\ ${ }^{1}$ Department of Home and Rural Economics, Federal College of Agriculture, Ishiagu, Ebonyi Nigeria \\ ${ }^{2}$ Department of Vocational Education, Abia State University, Uturu, Nigeria
}

Email address:

pastorchisommfm@yahoo.com (Agomoh-Adeoye Q. C.)

\section{To cite this article:}

Agomoh-Adeoye Q. C., Ezenwa H. C.. Evaluation of Blended Cooking Banana (Musa spp) and Soybean (Glycinemax (L.) Merrill) as Food Complement for Infants. Science Journal of Business and Management. Special Issue: Sustainable Entrepreneurial Developments in Agribusiness. Vol. 3, No. 5-1, 2015, pp. 26-29. doi: 10.11648/j.sjbm.s.2015030501.16

\begin{abstract}
This work evaluated infant complementary food based on cooking banana (Musa Spp.; popularly called 'unere nkpunkpu' in igbo dialect) and Soybean (Glycine max L. merrill) flours. The flours were blended in various proportions (80:20 (CSA), 60:40(CSB) and 40:60(CSC)). Aliquots of blend were taken for proximate analysis, vitamins and minerals determination. Twenty mothers were used for the sensory evaluation. In the proximate analysis, the ash, fat and crude protein values were higher $(\mathrm{P}<0.05)$ than the controls while the controls had higher $(\mathrm{P}<0.05)$ carbohydrates and energy values in dry weight matter. The mineral and vitamin determination indicate that iron, sodium, pro-vitamin A values of some of the mixes were higher than the controls. The controls had higher $(\mathrm{P}<0.05)$ values in vitamin $\mathrm{C}$ and calcium. There was no significant difference in their phosphorus levels. The porridges were mixed with water, cooked and sweetened with sugar to taste and presented to the panel (mothers). The results of the sensory evaluation showed that there were no significant differences ( $\mathrm{P}>0.05)$ in colour, taste, texture and the overall acceptability. It could be concluded therefore that other sources of phosphorus and vitamins when added to the porridge could make better meal than the controls. The results also showed that the formulated porridges were naturally richer than the controls in some nutrients. With the satisfactory nutritive value and functional characteristics of the composite flours, they can be recommended to the infants and young children.
\end{abstract}

Keywords: Complementary Foods, Cooking Banana, Composites/Blends, Nutriend, Pap and Soybean

\section{Introduction}

Most of the complementary foods marketed in developing countries are produced by roller drying or extrusion cooking. These are capital-intensive technologies, and the foods produced have large dietary bulk that limits children's nutrients intake (WHO/NUT, 1998) It is therefore desirable to develop low-cost complementary foods from locally available resources and adapting simple technologies, so that the foods can be produced by mothers, community, workers or government agencies and supplied at affordable prices. One of the simple traditional technologies that are being adapted for complementary foods is the steeping and dehulling of cereals and legumes.

Several strategies may be used to improve the nutritive value of complementary foods. The traditional West African complementary foods could be improved by combining locally available foods that complement each other in such a way that the new pattern of amino acids created by this combination is similar to those recommended for infants (Uwaegbute and Nnanyelugo, 1998). Similar studies have been done on cereal/legume combinations in Nigeria. Fashakin and Ogunsoola (1982) formulated nut-ogi (a mixture of corn gruel and peanut). Addo and Akeredolu (1985) formulated soy-ogi (corn gruel plus soy bean). Uwaegbute and Nnanyelugo (1998) formulated cereals (corn/rice, sorghum plus cowpea). Some of these combinations have been adopted in the food industries and the foods are available in the Nigerian market (Plahar and Hoyle, 1991).

Introduction of solids (complementary foods) is not recommended before the age of six months because the baby's digestive system is not able to digest solid foods. There is also no nutritional reason for giving any food other than breast milk or infant milk before four months. It is important to start 
complementary feeding from the age of six months. In 2001, World Health Organization (WHO) issued a revised global recommendation that mothers should continue breast-feeding exclusively for six months. At six months, breast or infant milk would not satisfy all the baby's nutritional needs. It is important from development point of view to start giving other foods (Uwaegbute, 1982). The economic situation in Nigeria has made it difficult for a lot of households to afford animal protein sources. In order therefore to prevent protein energy malnutrition, availability of cheaper plant protein sources such as soybeans, pulses and legumes need to be harnessed for appropriate infant feeding (Eka, 1998).

The objective of this paper therefore is to evaluate a low-cost and accessible complementary food using cooking banana and soybean that will be organoleptically and nutritionally acceptable. The utilization of cooking banana and soybean mixes would increase the utilization of our locally grown crops in the formulation of cheap or affordable and nutritive complementary food.

\section{Materials and Methods}

\subsection{Materials}

Major raw materials used for the experiment were slightly ripen cooked banana 'unere nkpunkpu' and dried soybean (Glycine max). These ingredients were purchased from a local market.

\subsection{Methods of Processing of Raw Materials}

One head of cooking banana (slightly ripe) was washed, peeled and rewashed with warm water. $2350 \mathrm{~g}$ of the banana was sliced to $2 \mathrm{~mm}$ sizes, dried, milled and finely sifted with plain white cotton clothing material. One thousand grams $(1000 \mathrm{~g})$ of whole grains of soyabean were picked, washed and boiled for 25 minutes, dehulled, dried, roasted, milled and finely sifted with cloth into flour.

\subsection{Composite Samples Preparation}

Preparation of composite flours (samples): The complementary foods were formulated by weighing the samples, using a sensitive scale (Sartorius digital weighing balance). The flours were blended in these ratios. Cooking banana + Soybean- 80:20 (CSA), 60:40 (CSB) and 40:60(CSC). Nutrend (NuD) -100\%. Pap (PpE) (flour)-100\%.

Preparation of porridges: Proportions were prepared from composite flours as well as the controls. One hundred grams $(100 \mathrm{~g})$ of each flour blends were mixed with $500 \mathrm{ml}$ water. The slurry was heated with continuous stirring at $75^{\circ} \mathrm{C}$ and allowed to boil for 10 minutes with constant heating. The gruel was allowed to cool at room temperature to $40^{\circ} \mathrm{C}$ (serving temperature). The samples were kept separately in thermos flasks to maintain the serving temperature of $40^{\circ} \mathrm{C}$.

\subsection{Chemical Analysis}

The laboratory analysis of the samples were conducted to determine the proximate composition (crude fiber' moisture, ash, crude fat and crude protein) of the flour blends using various methods. Carbohydrate was calculated by difference. Some vitamins (Pro-vitamin A and vitamin C) were estimated (Osagie and Eka, 1998) and usual titration methods (Barakat titrimetric method) was used for minerals (calcium, phosphorus, iron and sodium) (AOAC, 1990).

\subsection{Sensory Evaluation}

Twenty mothers were randomly selected from the mother and child health clinic of the Umuahia North Local Government area of Abia, Nigeria for sensory evaluation. The porridges were coded and about $200 \mathrm{ml}$ of each was presented to the judges from a thermos flasks. The parameters evaluated were colour, taste, texture and overall acceptability on a 7-point hedonic scale of;

1 - Dislike extremely, 2 - dislike moderately, 3 - dislike, 4 undecided, 5 - like, 6 - like moderately and 7 - like extremely. Where, Nutrend, a complementary food formulated by Nestle Foods and maize gruel (pap/ogi) were used as positive and negative controls respectively.

\subsection{Statistical Analysis}

Mean and standard deviation were calculated for variables. Analysis of variance and Duncan New Multiple Range Test (DNMRT) were used to separate and compare mean of the various proportions.

\section{Results and Discussion}

The result of the proximate analysis carried out on each blend is presented in Table 1.The result shows significant differences in energy content of the samples, the CSC had higher energy value among all the blends.

Table 1. Proximate Composition of Floor Blends (\% dry weight matter).

\begin{tabular}{|c|c|c|c|c|c|c|c|}
\hline $\begin{array}{l}\text { flour type and blend } \\
\text { CB:SYB }\end{array}$ & Energy (Kj) & $\begin{array}{l}\text { Moisture } \\
\text { Content (\%) }\end{array}$ & Ash (\%) & Crude Fiber (\%) & Fat (\%) & $\begin{array}{l}\text { Crude Protein } \\
(\%)\end{array}$ & $\begin{array}{l}\text { Carbohydrate } \\
(\%)\end{array}$ \\
\hline $\mathrm{CSA}^{*}$ & 1425.51 & 13.53 & 4.60 & 1.84 & 3.25 & 13.70 & 63.08 \\
\hline CSB & 1538.45 & 12.75 & 3.11 & 2.46 & 7.51 & 22.56 & 51.62 \\
\hline $\mathrm{CSC}$ & 1609.59 & 10.78 & 4.18 & 3.57 & 11.23 & 29.18 & 41.06 \\
\hline $\mathrm{NuD}$ & 1673.26 & 5.66 & 2.66 & 3.50 & 8.71 & 15.77 & 63.71 \\
\hline $\mathrm{PpE}$ & 1519.65 & 10.34 & 2.64 & 0.57 & 2.50 & 2.50 & 80.70 \\
\hline
\end{tabular}

*CSA-CB 80:SYB20.CSB-CB 60:SYB40. CSC-CB 40:SYB60. NuD-Nutrend and PpE-Pap. 
The CSC blend had the least moisture (10.78\%). On the other hand, the CSA ratio had highest moisture (13.53). NuD had the least moisture. The 20:80 CS1 ratio had the highest ash as against the other ratios (Table 2). Then CSC ratios followed. $\mathrm{NuD}$ and $\mathrm{PpE}$ had comparable values (2.66 and 2.64\%). The CSB and CSC blends had higher fiber than CSA blends. The PpE had the least value of $0.57 \%$. However, NuD had a similar value as that of the CSC (3.50 and 3.57\% respectively). The fat value for the CSA ratios was lower than other ratios. The CSC ratios were higher $11.23 \%$ than other blends as well as $\mathrm{NuD}(8.75 \%)$. The protein value for $\mathrm{PpE}$ was the least $(13.70 \%)$. There was a trend towards increase in crude protein as the ratios decreased from CSA to CSC (Table $1)$.

Table 2. The Mineral and Vitamin composition of Raw Materials (dry weight basis).

\begin{tabular}{lllllll}
\hline Sample & Calcium & Phosphorus & Iron & Sodium & ProVitamin A & Vitamin C \\
\hline $100 \%$ CB & 5.60 & 17.85 & 30.88 & 5.80 & 816.00 \\
$100 \%$ SYB & 206.80 & 555.00 & 7.30 & 18.40 & 183.00 \\
\hline
\end{tabular}

*CB - Cooking banana. SYB - Soy bean.

The PpE had the highest carbohydrate $(80.70 \%)$ content which differed significantly from the rest of the blends. The mean carbohydrate $(51.92 \%)$ for blends was lower than those of pap and NuD. The higher energy $(1673.59 \mathrm{~kJ})$. The lower moisture for $\mathrm{NuD}(5.66 \%)$ could be a result of the industrial preparation for good shelf life while the mixes were sundried. Processing technique is known to equally increase moisture. The high protein for CSB \& CSC (22.56\% \& 29.18\%) mixes demonstrated its superiority over other diets as source of protein. This was early reported by many that soy bean (glycine max L. merrill) is one of the legumes that had $40 \%$ protein and $20 \%$ polyunsaturated fat content. Blending the cooking banana with soybean flours increased protein due to their proportions and mutual supplementation effect. The high carbohydrate for CSA mix suggests that high ratio of $\mathrm{CB}$ produces more carbohydrate than other ratio (mixes). This is not a surprise because cooking banana is a starchy fruit.

The CSC (11.23\%) met the CAC/GL08-1991 standard for lipids (10-25\%). Where CSC (29.18\%) and the CSB (22.56\%) were higher in protein than $\mathrm{NuD}(15.77 \%)$ and met the CAC protein standard equally. $\mathrm{NuD}$ had higher calcium than all the mixes (390.00mg). Pap had the lowest calcium (16.40mg). The CSA mix had the least value against others $(45.88 \mathrm{mg})$ in Table 3.The CSC mix had high calcium content although lower than NuD (126.04 \& 390mg) 16. The mixes had higher phosphorus content than controls. However, when the ratio of banana was decreased there was an increase in phosphorus (Table 3). The blend CSC was higher in phosphorus (339.40mg) than $\mathrm{NuD}$. The CSA mix had higher iron than those other ratios.

Table 3. The Mineral and Vitamin composition of Flour blends.

\begin{tabular}{|c|c|c|c|c|c|c|}
\hline Flour type and blend & Calcium (mg/g) & Phosphorus (mg/g) & Iron (mg/g) & Sodium (mg/g) & Provitamin A (mg/g) & Vitamin C (mg/g) \\
\hline \multicolumn{7}{|l|}{ CB:SYB } \\
\hline CSA & 45.85 & 125.28 & 26.16 & 8.32 & 665.40 & 12.18 \\
\hline CSB & 87.05 & 232.69 & 21.45 & 10.83 & 561.80 & 11.83 \\
\hline $\mathrm{CSC}$ & 126.04 & 339.40 & 16.73 & 13.34 & 436.00 & 10.76 \\
\hline $\mathrm{NuD})$ & 390.00 & 260.00 & 10.00 & 2.20 & 500.00 & 50.00 \\
\hline $\mathrm{PpE}$ & 16.40 & 157.70 & 5.02 & 4.00 & 4.59 & 0.12 \\
\hline
\end{tabular}

The sodium concentration of the mixes was influenced by the ratio of banana to soy. However, as the ratios of banana decreased that of a soy bean increased, sodium level increased (8.32, 10.83 \& $13.34 \mathrm{mg}$ respectively). NuD and $\mathrm{PpE}$ had lower values $(2.20$ and $4.00 \mathrm{mg})$. The CSA had higher pro-vitamin A (665.40 \& 561.80) values than $\mathrm{NuD}$ and $\mathrm{PpE}$ (500.00 \& 4.59). This indicates that cooking banana is a good source of pro-vitamin A (Table 2) as pro-vitamin A values decreased with increase of soya bean and decreased in cooking banana. Vitamin $\mathrm{C}$ followed the same trend as pro-vitamin A as the proportions of cooking banana decreased 80 to 60 to $40 \%$ ) (Table 3 ) ascorbate values were reduced. The pap had the least value $(0.12 \mathrm{mg})$. On the other hand, $\mathrm{NuD}$ had the highest $(50.00 \mathrm{mg})$ as it has been industrially fortified. The high calcium and phosphorus values for the CSC suggest that this was the optimum ratio for increasing these nutrients using cooking banana. The higher value for calcium from $\mathrm{NuD}$ (390.00mg) strongly suggests that NuD had an edge over the other blends. The lower iron for pap as well as $\mathrm{NuD}$ (5.02 and $10.00 \mathrm{mg}$ ) might be associated with the processing. The analysis showed that the blends except 40:60 were rich in iron because of the high iron in cooking banana (musa spp.) as supported by Ogbuagu ${ }^{22}$. The lower sodium for 20:80 than other mixes could be explained as banana and soy bean are poor sources of sodium and as such would be a beneficial food to individuals who need low sodium diet. The high pro-vitamin A and C for 20:80 appear to suggest that cooking banana was a good source of both. It also suggests processing technique had no much adverse effect on the foods. They met the CAC standards for pro-vitamin A (400).

Sensory evaluation scores of porridges based on blends of Cooking Banana and Soybean, Nutrend and Pap (table 4). The $\mathrm{CBB}$ and $\mathrm{CBC}$ mixes had comparable colour values to $\mathrm{NuD}$ and $\mathrm{PpE}$ (4.7, 4.55, 4.90 and 5.15 respectively). There was an 
overall acceptability of all the mixes as well as $\mathrm{NuD}$ and $\mathrm{PpE}$ which have been popular complementary foods. The values for all the attributes were more than half of the standard scale (7- hedonic scale). Despite the mother's familiarity with the $\mathrm{NuD}$ and the PpE, no significances were observed in taste, texture and overall acceptability of these porridges, samples CSA, CSB, CSC, NuD and PpE. This supported the fact that soy bean flour is the major legume flour that has gained popularity for infant feeding in Nigeria. The comparable colours for the samples suggest that the judges equally accepted them. The similarities in taste, texture and overall acceptability (table 4) suggest that these attributes were equally acceptable to the judges - a commonly observed phenomenon.

Table 4. Sensory characteristics of porridges based on blends.

\begin{tabular}{lllll}
\hline Samples & Colour & Table & Texture & Overall Acceptability \\
\hline CSA & 4.0 & 4.60 & 4.90 & 5.30 \\
CSB & 4.7 & 5.30 & 5.10 & 5.70 \\
CSC & 4.55 & 5.05 & 4.95 & 5.35 \\
NUD & 4.90 & 5.35 & 4.80 & 5.15 \\
PPE & 5.15 & 5.15 & 4.80 & 5.55 \\
\hline
\end{tabular}

\section{Conclusions}

As judged by the result, blends of cooking banana: soy bean had good nutrient profiles as complementary foods. The porridges were moderately accepted as well as the Nutrend and the pap. Among all the proportions, the 60:40 blends was most organoleptically accepted (Uwaegbute et al., 1999). This shows that these blends are most likely to be accepted by consumers which should be promoted.

Protein and energy are major issues in Nigeria and complementary foods. This work showed increase in protein content of all blends. The 60:40 blends came closest to the commercial Nutrend and was higher than the traditional complementary gruel (pap). Although cooking banana (musa spp.) has low protein, it has commendable iron content compared with much lower value for legume. The sodium is low and the provitamin $\mathrm{A}$ and vitamin $\mathrm{C}$ are higher than legume. It will provide these nutrients while the legume provides needed protein. Cooking banana therefore, seems to be a good raw material for the production of complementary foods.

\section{References}

[1] WHO/NUT/98.1 (1998). Complementary deeding of young children in developing countries: a review of current scientific knowledge. Geneva: World Health Organization.

[2] Uwaegbute A C and Nnanyelugo DO (1998). Towards improving the nutritional value of traditional weaning foods. In Fashakin JB, ed. Proceedings of the workshop on present knowledge on weaning foods in Nigeria held in Lagos, $29^{\text {th }}$ $-30^{\text {th }}$ August, 1989. Oshodi - Lagos Institute of Industrial Research; 63- 85.

[3] Fashakin J.B and Ogunsoola F (1982). The utilization of Local foods in fermentation of weaning foods. Trop Paed (London); 28:93-6

[4] Addo A.A Akeredolu I.A (1995). Organoleptic and objective Evaluation Pearl Millet - Conophor Weaning mix; Nigeria. J. Nutr. Sa; 26(1): 13-18

[5] Plahar W.A and Hoyle N.T (1991). Estimated protein quality of weaning blends from local cereals and legumes. In Sefa-Deden S.Ed. The development of high protein energy foods from grain February 1991. Accra; University of Ghana: 75-87.

[6] Uwaegbute AC (1982). Infant feeding patterns comparative assessment of formulated weaning foods on vegetable proteins. Doctoral thesis. University of Nigeria Nsukka.

[7] Association of Official Analytical Chemists (AOAC) (1990). Official methods of analysis $15^{\text {th }}$ edn. Washington, D.C.USA.

[8] Osagie AU and Eka OU (1998). Nutritional Quality of Plant foods. Pp 53-83.

[9] Uwaegbute AC, Iroegbu CU and Ezeikpe DO (1999). Organolaptic and Nutritional Evaluation of Soybean fortified pap. Ecol. Of Food and Nutrition, Vol.38, pp 415-426.

[10] Eka OU (1998). Nutritive value of "tuwo" Shinkafa Da-Taushe, a traditional rice meal of the Hausas of Northern Nigerian. Nig. J. Nutr.Sci; 3:87-90. 